\author{
Krzysztof Chmielews ki, Maciej Pająk
}

\title{
Zasada humanitaryzmu w krajowych i międzynarodowych standardach prawa penitencjarnego
}

Humanitarny (od łacińskiego humanitas, czyli człowieczeństwo, ludzkość) oznacza stawiający za cel dobro człowieka ${ }^{1}$. Szkoła humanitaryzmu, będąca wyrazem sprzeciwu wobec bezprawia i okrucieństwa karania w Europie, zapoczątkowała szereg reform w ustawodawstwie epoki Oświecenia. Przeciwko systemowi prawa karnego państwa absolutnego występował włoski prawnik Cesare Beccaria ${ }^{2}$. W dziele O przestępstwach $i$ karach opowiedział się stanowczo przeciwko torturom oraz karze śmierci ${ }^{3}$. Dość szybko jego praca została przetłumaczona na wiele języków i wywołała dyskusję na temat karania w Europie. Wśród postulatów wysuwano: bezwarunkowe zniesienie kwalifikowanej kary śmierci, zaniechanie kar mutylacyjnych i hańbiących, wprowadzenia kary pozbawienia wolności urządzonej w sposób zapewniający wychowanie sprawcy ${ }^{4}$, zniesienie tortur jako środka uzyskania dowodu w postaci przyznania się oskarżonego. W duchu epoki powstał w 1787 roku austriacki kodeks karny, Constitutio Criminalis Josephina, który uwzględniał postulaty humanitarystów szczególnie w odniesieniu do zasad: nullum crimen sine lege oraz nulla poena sine lege. Nie tylko pewność prawa była wartością w owym kodeksie, bowiem zawierał również nowoczesne przepisy prawa wykonawczego. Kary pozbawienia wolności różniły się zarówno pod względem czasu trwania (czasowe, długie i długotrwałe), jak i pod względem rygoru (łagodne ciężkie i najcięższe) 5 $^{5}$ Dziś wykonywanie kary pozbawienia wolności w rygorze najcięższym, to jest przykucie w dzień i w nocy w pomieszczeniach pozbawionych światła i świeżego powietrza, zostałoby najpewniej podane w wątpliwość co do zgodności z humanitarnym traktowaniem. Z kolei

1 J. Okramus, M. Tytuła, Stownik wyrazów obcych, Warszawa-Bielsko-Biała 2013, s.94.

2 A. Dziadzio, Powszechna historia prawa, Warszawa 2009, s. 150.

3 Beccaria czerpał inspirację z poglądów Monteskiusza, którego uważa się za prekursora humanitaryzmu. Dzieło Beccari zostało wydane po raz pierwszy w Livorno w 1764 roku.

4 Kara pozbawienia wolności miała być karą podstawową, zaś wiezienia urządzone w sposób „humanitarny”.

5 A. Dziadzio, op. cit., s. 154. 
kodyfikacja kojarzona z oświeceniowym władcą Fryderykiem II, Landrecht pruski z 1794 roku, wobec złodziei recydywistów przewidywała jedną z kar nieoznaczonych, mianowicie umieszczenie w domu pracy celem nauki zarobkowania, co stanowiło o wyraźnej zmianie założeń stosowania kary, jaka towarzyszyła oświeceniowym przeobrażeniom.

Mimo że oświeceniowe ustawodawstwo karne zbliżało się do urzeczywistniania idei humanitaryzmu, wykonywanie kary pozbawienia wolności odbywało się w ciężkich warunkach. Współcześnie, rozprawiając o humanitarnym traktowaniu osób pozbawionych wolności, można mówić o trzech systemach ochrony, zróżnicowanych ze względu na zasięg: krajowych, regionalnych i ponadnarodowych.

$Z$ ideą humanitaryzmu w wykonywaniu kary pozbawienia wolności wiążą się pryncypialne zasady: poszanowania godności, zakazu tortur oraz okrutnego lub poniżającego traktowania albo karania. Zasady owe zostaną omówione w dalszej części opracowania, która dotyczy poszczególnych systemów ochrony praw człowieka. Warto zauważyć, że analiza zagadnienia dotyczy nie tylko stanowienia prawa, ale również jego egzekwowania. W tej części pracy zostaną omówione mechanizmy sądowe i pozasądowe ochrony praw człowieka. Humanitaryzm to również zapewnienie odpowiednich warunków socjalno-bytowych - tu zostaną wskazane takie kwestie, jak: warunki bytowe, sanitarno-higieniczne, kulturalno- oświatowe, warunki zatrudnienia więźniów oraz kontakt ze światem zewnętrznym.

\section{Humanitarne traktowanie więźniów a prawo krajowe}

Za punkt wyjścia rozważań należy przyjąć zasadę wyrażoną w art. 30. Konstytucji Rzeczypospolitej ${ }^{6}$, iż „przyrodzona i niezbywalna godność człowieka stanowi źródło wolności i praw człowieka i obywatela”. Owa godność jest nienaruszalna, zaś na władze publiczne został nałożony obowiązek jej poszanowania i ochrony. Również w preambule polskiej ustawy zasadniczej znajduje się odesłanie do zachowania przyrodzonej godności człowieka. Zasada ta stanowi aksjologiczną podstawę całego systemu prawnego ${ }^{7}$. Konstytucja jako najwyższy akt prawa stanowionego w RP zakazuje okrutnego, nieludzkiego lub poniżającego traktowania i karania (art. 40), zdanie drugie tegoż artykułu zakazuje również stosowanie kar cielesnych. Zasada humanitaryzmu w Konstytucji została expressis verbis wyrażona w art. 40. ust. 4., który stanowi, że „każdy pozbawiony wolności powinien być traktowany w sposób humanitarny”. Należy zwrócić uwagę, że użyte pojęcia nie posiadają definicji legalnych. Według Pawła Sarneckiego, humanitarne traktowanie to takie obchodzenie się z osobą pozbawioną wolności, które uwzględnia i respektuje pewne minimalne potrzeby każdego człowieka, odnosząc je do przeciętnych

6 Konstytucja Rzeczypospolitej Polskiej z dn. 2 kwietnia 1997 r.(Dz.U. Nr 78, poz.483 z późn.zm.).

7 E. Dawidziuk, Traktowanie osób pozbawionych wolności we wspótczesnej Polsce na tle standardów międzynarodowych, Warszawa 2013, s. 14. 
standardów danego społeczeństwa ${ }^{8}$. Można również przyjąć definicję negatywną, w myśl której „za niehumanitarne uznać należy takie działania organów władzy państwowej, które - nie służąc bezpośrednio założonym celom kary pozbawienia wolności - prowadzą do udręki fizycznej skazanych, do poniżania ich godności osobistej, uszczuplania ich praw albo uniemożliwiania im ochrony swoich praw" ${ }^{9}$. W odniesieniu do wymienionych zasad Trybunał Konstytucyjny stwierdza, że niedookreślony, a przez to w praktyce nieograniczony czas stosowania ograniczeń praw i wolności konstytucyjnych w stosunku do skazanych i brak możliwości obrony tych praw stanowią rażące naruszenie zasady określonej w art. 41. ust. 4 i art. 40. Konstytucji. W ocenie sądu wolność nieludzkiego i poniżającego ma charakter absolutny i nie może być w żadnych warunkach ograniczona. W tej kwestii zajął wyraźne stanowisko, że wzorce kontroli - art. 40 i art. 41 ust. 4 - nie mogą być łączone z wzorcem zawartym w art.31. ust. 3 Konstytucji, który określa warunki i granice ograniczenia konstytucyjnych praw i wolności. $Z$ orzecznictwa Trybunału Konstytucyjnego można wywnioskować, że Trybunał uznaje absolutny charakter wolności od niehumanitarnego traktowania. Co więcej, nie może ona podlegać ograniczaniu w drodze ustawowej, choćby $z$ tak ważnych przesłanek jak wymienione w art. 31 ust. 3, czyli bezpieczeństwo lub porządek publiczny, bądź dla ochrony środowiska, zdrowia i moralności publicznej albo wolności i praw innych osób. Wagę owej zasady podkreśla również art. 233 ust. 1 Konstytucji, który zakazuje ograniczania w trakcie stanu wojennego lub wyjątkowego wolności i praw określonych w art. 30, 40 i 41 ust. 4 Konstytucji. Ta istotna gwarancja nie występowała w poprzednich polskich ustawach zasadniczych ${ }^{10}$.

W uzasadnieniu Kodeksu karnego wykonawczego wskazano jako źródło inspiracji „wartości ogólnoludzkie przyjmowane w cywilizowanym świecie”11. Owe wartości według ustawodawcy odnaleźć można w koncepcji praw człowieka, odzwierciedlonej zwłaszcza w Powszechnej Deklaracji Praw Człowieka, Międzynarodowym Pakcie Praw Obywatelskich i Politycznych, Regułach Minimalnych oraz Europejskich Regułach Penitencjarnych.

Zasada humanitaryzmu i poszanowania godności ludzkiej znajduje wyraz w art. $3 \mathrm{k}$. k. ${ }^{12}$ oraz art. 4 k. k. w. ${ }^{13}$. Według art. 4 k. k. w. środki karne, zabezpieczające i zapobiegawcze wykonuje się w sposób humanitarny, z poszanowaniem godności ludzkiej skazanego; zakazuje się tortur lub nieludzkiego albo poniżającego traktowania i karania. Art. 4 ma charakter programowy, stanowi ogólną dyrektywę dla stosowania przepisów karnych

8 P. Sarnecki, Komentarz do art. 41 Konstytucji RP, [w:] Konstytucja Rzeczypospolitej Polskiej. Komentarz, t.III, red. Leszek Garlicki, Warszawa 2003, s. 8.

9 Wyrok Trybunału Konstytucyjnego z dnia 26 maja 2008 r., sygn. akt SK 25/07.

10 E. Dawidziuk, op. cit., s. 16.

11 Uzasadnienie do projektu Kodeksu karnego wykonawczego z 1997 r., druk sejmowy nr 1278, Sejm Rzeczypospolitej Polskiej II kadencji.

12 Ustawa $z$ dnia 6 czerwca 1997 r.- Kodeks karny (Dz.U. Nr 88, poz. 553 z późn zm.).

13 Ustawa z dnia 6 czerwca 1997 r.- Kodeks karny wykonawczy (Dz.U. Nr 90, poz.557 z późn. zm.). 
wykonawczych ${ }^{14}$. Zasada humanitaryzmu w nim wyrażona, co wynika $z$ tytułu rozdz. III k. k. w., odnosi się do szczególnej kategorii, jaką jest skazany. Należy jednak w tym miejscu zaznaczyć, że naczelna zasada dotyczy również tymczasowo aresztowanych.

K. k. w. określa także kompetencje sędziego penitencjarnego w zakresie nadzoru penitencjarnego (art. 33 i n. k. k. w.) wzmacniającego gwarancję przestrzegania praw więźnia. Sędzia ma prawo wizytowania obiektów, w których przebywają osoby pozbawione wolności, przeglądania dokumentów oraz żądania wyjaśnień od administracji tych jednostek. W trakcie wizytacji sędzia penitencjarny może przyjmować skargi, wnioski i prośby oraz rozmawiać z osobami pozbawionymi wolności bez obecności innych osób. Ponadto przysługuje mu uprawnienie kontrolne do uchylania sprzecznych z prawem decyzji dyrektora zakładu karnego, dyrektora aresztu śledczego, dyrektora okręgowego Służby Więziennej, kuratora sądowego, a nawet Dyrektora Generalnego Służby Więziennej, o ile dotyczą one osoby pozbawionej wolności. Jedynie w odniesieniu do decyzji komisji penitencjarnej to sąd wszczyna postępowanie z urzędu na mocy art. 76 § $2 \mathrm{k}$. k. w. Należy dostrzec rolę sędziego penitencjarnego w przestrzeganiu praw pozbawionych wolności, który zgodnie z art. 32. k. k. w. sprawuje nadzór nad legalnością i prawidłowością wykonywania kary pozbawienia wolności.

W stadium wykonawczym nie jest istotny stopień społecznej szkodliwości czynu bądź winy. Celem postępowania karnego wykonawczego jest prewencja ogólna, której zakres definiuje art. 67 §1 k. k. w. jako wzbudzanie w skazanym woli współdziałania w kształtowaniu jego społecznie pożądanych postaw, w szczególności poczucia odpowiedzialności oraz potrzeby przestrzegania porządku prawnego i tym samym powstrzymywania się od powrotu do przestępstwa. Dla osiągnięcia tego dalekosiężnego celu prowadzi się zindywidualizowane oddziaływanie na skazanych w określonych systemach wykonywania kary, w różnych rodzajach i typach zakładów karnych. W oddziaływaniu na skazanych powinno się zatem uwzględniać ich pracę sprzyjającą zdobyciu kwalifikacji zawodowych, zajęcia kulturalno-oświatowe i sportowe, podtrzymywanie kontaktów z rodziną i światem zewnętrznym oraz środki terapeutyczne ${ }^{15}$.

Nadto warto przytoczyć uprawnienia skazanego, o których mowa w art. 102 k. k. w., do:

- odpowiedniego ze względu na zachowanie zdrowia wyżywienia, odzieży, warunków bytowych, pomieszczeń oraz świadczeń zdrowotnych i odpowiednich warunków higieny,

- utrzymywania więzi z rodziną i innymi osobami bliskimi,

14 A. Marek, Kodeks karny. Komentarz, Warszawa 2010, s. 17 i n.

15 A. Gerecka-Zołyńska, W. Sych, Prawo karne wykonawcze. Zagadnienia procesowe, Warszawa 2014, s.55. 
- korzystania z wolności religijnej,

- otrzymywania związanego z zatrudnieniem wynagrodzenia oraz do ubezpieczenia społecznego w zakresie przewidzianym w odrębnych przepisach, a także pomocy w uzyskiwaniu świadczeń inwalidzkich,

- kształcenia i samokształcenia oraz wykonywania za zgodą dyrektora zakładu karnego do wytwarzania i zbywania wykonanych przedmiotów,

- korzystania z urządzeń i zajęć kulturalno-oświatowych oraz sportowych, radia, telewizji, książek i prasy,

- komunikowania się z obrońcą, pełnomocnikiem, właściwym kuratorem sądowym oraz wybranym przez siebie przedstawicielem,

- komunikowania się z przedstawicielami stowarzyszeń, fundacji, organizacji oraz instytucji związanych ze społeczną readaptacją skazanych, a także z kościołami i innymi związkami wyznaniowymi,

- zapoznawania się z opiniami sporządzonymi przez administrację zakładu karnego, stanowiącymi podstawę podejmowanych wobec niego decyzji,

- składania wniosków, skarg i próśb organowi właściwemu do ich rozpatrzenia oraz przedstawiania ich, w nieobecności innych osób, administracji zakładu karnego, kierownikom jednostek organizacyjnych Służby Więziennej, sędziemu penitencjarnemu, prokuratorowi i Rzecznikowi Praw Obywatelskich,

- prowadzenia korespondencji z organami ścigania, wymiaru sprawiedliwości i innymi organami państwowymi, organami samorządu terytorialnego, Rzecznikiem Praw Obywatelskich, Rzecznikiem Praw Dziecka oraz organami powołanymi na podstawie ratyfikowanych przez Rzeczpospolitą Polską umów międzynarodowych dotyczących ochrony praw człowieka.

Przez wzgląd na użycie przez ustawodawcę wyrażenie „w szczególności” należy przyjąć, że charakter wymienionych w powyższym artykule praw skazanego nie ma charakteru wyczerpującego. Odnosząc wymienione uprawnienia skazanego do uprawnień przysługujących skazanemu pod rządami pierwotnej wersji kodeksu karnego wykonawczego z 1969 roku' ${ }^{16}$, dostrzec można dysproporcje w tym katalogu. Rozdział IV uprzednio obowiązującego kodeksu zatytułowany „Skazany” przyznał mu prawo składania wniosków i skarg, ustanowił zasadę, że ograniczenie praw nie może przekraczać granic niezbędnych do prawidłowego wykonania kary lub środka karnego, a także w §3 wskazał, że kary wykonuje się w sposób humanitarny z poszanowaniem godności ludzkiej skazanego. Nadzór nad wykonaniem kary prowadził sędzia penitencjarny i prokurator. W części szczególnej kodeksu karnego wykonawczego z 1969 r., w dziale XI została nadto podkreślona funkcja resocjalizacyjna kary pozbawienia wolności, która miała być

16 Ustawa z dnia 19 kwietnia 1969 r.- Kodeks karny wykonawczy (Dz.U. Nr 13, poz.98). 
kreowana zwłaszcza przez pracę naukę i zajęcia kulturalno-oświatowe. Katalog uprawnień skazanego z k.k.w. z 1997 r. jest więc szerszy, obejmuje również chociażby prawo do praktyk religijnych, które w okresie obowiązywania poprzedniego kodeksu nie były politycznie pożądane. W owym porównaniu należy też zadać pytanie o rzeczywiste stosowanie postanowień kodeksu do obywających karę pozbawienia wolności. Mimo wysłowionej również zasady humanitaryzmu, może być to wątpliwe.

Zasadę ogólną wprowadza również k. k., który stanowi, że kary oraz inne środki stosuje się z uwzględnieniem zasad humanitaryzmu, w szczególności z poszanowaniem godności człowieka. Zastrzeżenie odnosi się do wszystkich etapów stosowania kary, a więc także do jej wykonania ${ }^{17}$. Zasadę humanitaryzmu należy rozumieć jako dyrektywę minimalizowania cierpień, dolegliwości i innych niedogodności zadawanych człowiekowi przy stosowaniu kar kryminalnych oraz ich wymierzania tylko wtedy i w takich granicach, w jakich jest to konieczne dla realizacji norm prawa karnego ${ }^{18}$.

Ustawodawca, opracowując Kodeks karny, wziął pod uwagę zarówno dobra osobiste pokrzywdzonego, jak i sprawcy przestępstwa. Sprzeczne z dyrektywą humanitaryzmu w opinii Sądu Apelacyjnego w Krakowie jest nadmierne odwlekanie wykonania kary ${ }^{19}$. Wówczas kara, w opinii sądu, nie służy poprawie skazanego, stając się abstrakcyjną dolegliwością oderwaną od dawnych czynów. Ponadto, długotrwałe oczekiwanie na wykonanie kary orzeczonej może prowadzić do destabilizacji życia skazanego w sferze jego stosunków osobistych i zawodowych ${ }^{20}$. Należy jednak dostrzec wyjątek w sytuacji, gdy za odroczeniem wykonania kary przemawia przykładowo zły stan zdrowia skazanego ${ }^{21}$. Ideę humanitaryzmu urzeczywistnia także możliwość ubiegania się przez skazanego o wcześniejsze, przedterminowe zwolnienie - Art. 78. § 1 k. k. wskazuje, że skazanego można warunkowo zwolnić po odbyciu co najmniej połowy kary. Inny warunek określa dla recydywisty wymienionego w art. 64 1, którego można warunkowo zwolnić po odbyciu dwóch trzecich kary, natomiast określonego w art. 64 § 2 po odbyciu trzech czwartych kary. $Z$ kolei skazanego na karę 25 lat pozbawienia wolności można warunkowo zwolnić po odbyciu 15 lat kary, natomiast skazanego na karę dożywotniego pozbawienia wolności, po odbyciu 25 lat kary. Założeniem warunkowego zwolnienia jest konieczność odbycia przez skazanego określonego minimum kary pozbawienia wolności. Uzasadnia to możliwość rozważania zwolnienia skazanego z reszty odbycia kary, o ile postawiona zostanie dla niego pozytywna prognoza kryminologiczna.

Treści art. 3 k. k. dopełnia przepis penalizujący fizyczne znęcanie się nad osoba pozbawioną wolności, którego sankcja karna jest tożsama ze znęcaniem się nad osoba najbliż-

17 W. Wróbel, A. Zoll, Polskie prawo karne. Częśc ogólna, Kraków 2010, s. 313 i 425.

18 A. Wąsek, Kodeks karny. Komentrarz, t.I, Gdańsk 1999, s.52.

19 Postanowienie Sądu Apelacyjnego w Krakowie z dnia 27 czerwca 2000, II Akz 232/00.

20 A. Gerecka-Zołyńska, W. Sych, op. cit., s. 55.

21 E. Dawidziuk, op.cit., s. 20. 
szą lub podwładnym żołnierzem. Art. 274 k. k. zakłada zagrożenie karą od 3 miesięcy do 5 lat pozbawienia wolności, zaś jeśli sprawca działa ze szczególnym okrucieństwem, typ kwalifikowany przewiduje karę od roku do 10 lat pozbawienia wolności. Przepis ma szczególne znaczenie w kwestii torturowania osadzonych, bo choć kodeks nie posługuje się pojęciem tortur znanym prawu międzynarodowemu, bez wątpienia czyn stypizowany w art. 274 k. k. może nosić znamiona tortur bądź innych niedopuszczalnych form traktowania więźnia. W uzasadnieniu postanowienia Sądu Najwyższego z dnia 29 lipca 1997 roku tortury definiowane są jako umyślne, nieludzkie traktowanie, powodujące poważne i okrutne cierpienia, zaś za nieludzkie traktowanie lub karanie uznawane jest takie, które polega na zadawaniu ciężkiego fizycznego i psychicznego cierpienia, natomiast poniżające traktowanie lub karanie to takie, które ma na celu wzbudzenie u ofiary uczucia strachu, udręki lub poczucia niższości, powodujące upokorzenie i upodlenie, ma złamać fizyczną i moralną odpornośćc ${ }^{2}$. Postanowienie dotyczyło wniosku o ekstradycję obywateli Chińskiej Republiki Ludowej, gdzie Sąd Najwyższy orzekł w sentencji, że

wydanie osoby ściganej w sytuacji istnienia prawdopodobieństwa poddania jej w kraju wzywającym torturom lub nieludzkiemu albo poniżającemu traktowaniu lub karaniu, w rozumieniu art. 3 Konwencji o Ochronie Praw Człowieka i Podstawowych Wolności z dnia 4 listopada 1950 r. (Dz. U. z 1993 r. Nr 61, poz. 284), jest prawnie niedopuszczalne.

W doktrynie podnosi się, że przepis statuujący zasadę humanitaryzmu zapewnia gwarancję jej poszanowania tak na etapie orzekania kar i środków karnych, jak i ich wykonywania ${ }^{23}$. Należy przy tym odróżnić faktyczne oraz ustawowe ograniczenia praw więźniów ${ }^{24}$. Ograniczenia faktyczne mogą polegać przykładowo na ograniczeniach w korzystaniu z praw przez więźniów zaliczanych do kategorii tak zwanych więźniów pokrzywdzonych oraz ograniczenia będące efektem przeludnienia zakładów karnych, czy też ograniczaniu innych warunków socjalno-bytowych lub kulturalno-oświatowych. Do ograniczeń ustawowych z kolei, należy zaliczyć kary dyscyplinarne przewidziane w art. 142-149 k. k. w.

Kodeks karny wykonawczy przewiduje następujące kary dyscyplinarne: - naganę, pozbawienie wszystkich lub niektórych nie wykorzystanych przez skazanego nagród lub ulg albo zawieszenie ich wykonania, na okres do 3 miesięcy,

22 II KKN 313/97, OSNKW 1997, z. 9-10, poz. 85.

23 K. Dąbkiewicz, Kodeks karny wykonawczy. Komentarz., Warszawa 2012, s. 38-39.

24 T. Bulenda, Faktyczne i ustawowe ograniczenia praw więznów [w:] Wykonywanie kary pozbawienia wolności w Polsce - w poszukiwaniu skuteczności, red. Henryk Machel, Gdańsk 2006, s. 295-309. 
- pozbawienie korzystania z udziału w niektórych zajęciach kulturalno-oświatowych lub sportowych, $\mathrm{z}$ wyjątkiem korzystania $\mathrm{z}$ książek i prasy, na okres do 3 miesięcy, - pozbawienie możliwości otrzymania paczek żywnościowych, na okres do 3 miesięcy, - pozbawienie lub ograniczenie możliwości dokonywania zakupów artykułów żywnościowych lub wyrobów tytoniowych, na okres do 3 miesięcy,

- udzielanie widzeń w sposób uniemożliwiający bezpośredni kontakt z osobą odwiedzającą, na okres do 3 miesięcy, - obniżenie przypadającej skazanemu części wynagrodzenia za pracę, nie więcej niż o 25\%, na okres do 3 miesięcy, umieszczenie w celi izolacyjnej na okres do 28 dni.

Nie ulega wątpliwości, iż sama instytucja kar dyscyplinarnych spełnia konstytucyjny wymóg proporcjonalności, co do formalnych i materialnych przesłanek ograniczenia praw i wolności.

Primo, problematyka kar dyscyplinarnych została uregulowana ustawie, czyniąc zadość obligatoryjnej formie wprowadzania ograniczeń.

Secundo, ustanowienie kar dyscyplinarnych uzasadnione jest koniecznością ochrony wartości wymienionych w art. 31 ust. 3 Konstytucji RP, w wymienionym przypadku: porządku publicznego oraz wolności i praw innych osób.

Tertio, uwzględniając kontekst społeczny i prawny, w jakim kary dyscyplinarne są stosowane, należy uznać, że nie naruszają one istoty ograniczanych praw i wolności. Izolacja penitencjarna to życie w pewnej społecznej zbiorowości, a w każdej zbiorowości obowiązują określone zasady i obowiązki, mające na celu zapewnienie porządku i bezpieczeństwa. Niepodporządkowanie się zasadom, niewypełnienie obowiązków powoduje określone konsekwencje ${ }^{25}$.

\section{Regulacje pozakodeksowe}

Pozakodeksowym uregulowaniem odnoszącym się do właściwego traktowania więźniów jest ustawa o Służbie Więziennej (Dz.U. Nr 79, poz. 523 z późn. zm.).Jako zadanie Służby Więziennej zostało wymienione przestrzeganie praw osób pozbawionych wolności, zwłaszcza zapewnienie humanitarnych warunków bytowych, poszanowanie godności, zapewnienie opieki zdrowotnej i religijnej (art. 2 ust. 2 pkt 3). Obok humanitaryzmu ustawa wymienia dyrektywę bezstronności oraz praworządności jako podstawy traktowania przez Służbę Więzienną (art. 27 pkt. 1 i 2).Jednak z treści ślubowania funkcjonariusza usunięto sformułowanie dot. kierowania się zasadami humanizmu ${ }^{26}$.

25 G. Szczygieł, Postępowanie dyscyplinarne w kodeksie karnym wykonawczym w Europejskie Reguty Więzienne z 2006 r., [w:] „Białostockie Studia Prawnicze” 2014 z. 15, s. 211-224.

26 Ustawa z dnia z dnia 9 kwietnia 2010 r. o Służbie Więziennej (Dz.U. 2010 nr 79 poz. 523). 
Elementy zasad humanitarnego traktowania w prawie krajowym znajdują się również w aktach rangi podstawowej. Rozporządzenia do k. k. w. dotyczą między innymi: zasad i trybu nauczania w zakładach karnych, warunków bytowych osób osadzonych, opieki leczniczej i ambulatoryjnej. Wymienione elementy traktowania muszą jednak być zgodne $\mathrm{z}$ zasadą humanitaryzmu wyrażoną w aktach wyższego rzędu.

\section{Akty prawa międzynarodowego}

\section{System ONZ}

Szczególnie ważne w dziedzinie ochrony praw człowieka było uchwalenie w 1948 roku Powszechnej Deklaracji Praw Człowieka. Mimo istnienia sporu co do mocy wiążącej bowiem nie jest umową międzynarodową - nie sposób nie docenić jej znaczenia moralnego i politycznego ${ }^{27}$. W art. 5. został wyrażony zakaz tortur lub okrutnego, nieludzkiego albo poniżającego traktowania czy karania. Art. 8 formułuje prawo do ochrony sądowej $\mathrm{w}$ razie pogwałcenia podstawowych praw przyznanych przez prawo wewnętrzne, zaś art. 10 prawo do rzetelnego sądu. Wskazane artykuły, pomimo ich postulatywnego charakteru i braku mocy wiążącej, stały się fundamentem do przyjęcia założeń Deklaracji w późniejszych gwarantujących przestrzeganie praw osób pozbawionych wolności aktach prawa międzynarodowego.

Soft law z zakresie polityki penitencjarnej stanowią także „Wzorcowe reguły minimum postępowania z więźniami”, będące efektem prac I Kongresu ONZ, który odbył się w Genewie w 1955 roku. Dokument ten w swojej pierwotnej wersji obejmował 94 reguły. Są raczej apelem moralno-politycznym niż aktami bezwzględnie zobowiązującymi państwa do określonego postępowania ${ }^{28}$. Nie dziwi więc brak jakiegokolwiek mechanizmu sankcji w przypadku nienależytego wypełniania lub naruszania przez państwa ich postanowień. Niemniej dały one asumpt do dyskusji na szczeblu międzynarodowym na temat praw przysługujących osobom pozbawionym wolności. Zbiór tych reguł był inspiracją dla twórców ich europejskiego odpowiednika ${ }^{29}$. Spośród nich warto wymienić wiodące cele „Reguł minimalnych ONZ”: pełne zabezpieczenie praw więźniów w czasie ich pobytu w zakładzie karnym oraz promowanie takiego modelu penitencjarnego oddziaływania na więźniów, który oparty jest na idei progresji społecznej i rehabilitacji tych osób. Na szczególną uwagę zasługuje Reguła 31, która wymienia rodzaje kar całkowicie zakazanych. Zaliczono do nich: kary cielesne, karę osadzenia w ciemnicy oraz kary nieludzkie, okrutne i poniżające. W przypadku zastosowania kary ścisłej izolacji oraz ograniczenia racji żywnościowej zastrzeżono obowiązek uprzedniego zbadania więźnia

27 J. Hołda, Z. Hołda, D. Ostrowska, J. Rybczyńska, Prawa cztowieka. Zarys wykładu, Warszawa 2014, s. 55.

28 D. Gajdus, B. Gronowska, Europejskie Standardy Traktowania Więzniów, Toruń 1998, s. 26.

29 Ibidem, s. 27. 
przez lekarza i zaświadczenia przez niego na piśmie, że więzień jest zdolny do odbycia wymierzonej kary dyscyplinarnej.

Status umowy międzynarodowej miały za to przyjęte Międzynarodowy Pakt Praw Obywatelskich i Politycznych oraz Międzynarodowy Pakt Praw Gospodarczych, Społecznych i Kulturalnych, które Polska ratyfikowała w 1977 roku $^{30}$. Pierwszy z wymienionych, w art. 7 potwierdził zakaz tortur lub okrutnego, nieludzkiego albo poniżającego traktowania lub karania. Art. 10 Paktu stanowi, że „każda osoba pozbawiona wolności będzie traktowana w sposób humanitarny i z poszanowaniem przyrodzonej godności człowieka”. Instytucją stojącą na straży przestrzegania Paktu jest Komitet Praw Człowieka, który rozpatruje skargi indywidualne na mocy Protokotu Fakultatywnego do Międzynarodowego Paktu Praw Obywatelskich i Politycznych z 1966 r. Komitet Praw Człowieka przyjmuje skargi od osób fizycznych, jak również skargi międzypaństwowe. Nie ulega wątpliwości, że już samo zgłaszanie sprawy o naruszenie praw przyczynia się do jej nagłośnienia i wywiera presję na społeczność międzynarodowąa ${ }^{31}$ Orzeczenia Komitetu Praw Człowieka dotykające bezpośrednio art.10 MPPOiP są stosunkowo nieliczne, gdyż w większości przedmiotem uwagi Komitetu była kwestia stosowania tortur, a także, $\mathrm{w}$ nieco mniejszym stopniu, poddawania okrutnemu, nieludzkiemu albo poniżającemu traktowaniu ${ }^{32}$. Komitet Praw Człowieka uznał, że warunki odbywania kary pozbawienia wolności nie mogą stanowić źródła tortury dla osoby skazanej. Wskazał w jednym z orzeczeń, że naruszeniem zasady humanitaryzmu jest umieszczenie osoby w podziemnej celi, w całkowitym odosobnieniu. Naruszeniem tej zasady jest także przetrzymywanie osoby w ciasnej komórce, w ciężkich warunkach, na które składają się między innymi obecność owadów w celi, nieodpowiednia temperatura w lecie i zimie, a także brak jakiejkolwiek wentylacji oraz brak światła ${ }^{33}$. Innym przykładem naruszenia art. 10 Paktu było przetrzymywanie aresztowanego w celi bez materaca i posłania, wentylacji, światła, urządzeń sanitarnych, czystej wody pitnej oraz pozbawienie lekarstw ${ }^{34}$.

Obok Komitetu Praw Człowieka należy wskazać Komitet Przeciwko Torturom, który rozpatruje skargi indywidualne zgodnie z artykułem 22. Konwencji w Sprawie Zakazu Stosowania Tortur oraz Innego Okrutnego, Nieludzkiego lub Poniżajacego Traktowania albo Karania z 1984 roku. Komitet przyjmuje skargi od osób fizycznych, jak również skargi międzypaństwowe. Konwencja już w art. 1 ust. 1 zawiera definicję tortur jako:

30 Dz. U. Nr 38, poz. 167 i 169.

31 J. Migdał, T. Szymanowski, Prawo karne wykonawcze i polityka penitencjarna, Warszawa 2014, s. 53.

32 W. Sobczak, Komentarz do Miedzynarodowego Paktu Praw Obywatleskich i Politycznych, [w:] Międzynarodowy pakt praw obywatelskich (osobistych) i politycznych. Komentarz, red. Roman Wieruszewski, Warszawa 2012.

33 Decyzja Komitetu Praw Człowieka z dnia 6 listopada 2003r., 1096/2002, Kurbanov p. Tadżykistanowi.

34 Decyzja Komitetu Praw Człowieka z dnia 23 marca 1999r., 775/1997, Brown p. Jamajce. 
każde działanie, którym jakiejkolwiek osobie zadaje się ostry ból lub cierpienie fizyczne bądź psychiczne, w celu uzyskania od niej lub od osoby trzeciej informacji lub wyznania w celu ukarania jej za czyn popełniony przez nią lub osobę trzecią albo o którego dokonanie jest ona podejrzana, a także w celu zastraszenia lub wywarciu nacisku na nią lub trzecią osobę albo w jakimkolwiek innym celu wynikającym $\mathrm{z}$ wszelkiej formy dyskryminacji, gdy taki ból lub cierpienie powodowane są przez funkcjonariusza państwowego albo inną osobę występującą w charakterze urzędowym lub z ich polecenia albo za wyraźną lub milczącą zgodą.

\section{System Europejski}

\section{Konwencja o ochronie praw człowieka i podstawowych wolności}

Zasadnicze znaczenie w ochronie praw człowieka w Europie ma Konwencja o ochronie praw człowieka i podstawowych wolności podpisana w Rzymie dnia 4 listopada 1950 roku (Dz. U. z 1993 r. Nr 61, poz. 284, z późn. zm.; dalej: Konwencja). Omawiany pakt jest regionalnym odpowiednikiem omówionego wyżej Międzynarodowego Paktu Praw Obywatelskich i Politycznych ${ }^{35}$. Należy przy tym wskazać na efektywność Konwencji, bowiem określiła procedury zaskarżania spraw o naruszenie praw, przewidując następstwa mające zadośćuczynić poszkodowanym. Organem, który na mocy Konwencji został wprowadzony do systemu Rady Europy jest Europejski Trybunał Praw Człowieka, jest niezawisłym, międzynarodowym sądem wyposażonym w kompetencje do orzekania określonych sankcji. Znaczenie orzeczeń ETPC jest o tyle istotne, że przewiduje odpowiedzialność odszkodowawczą państw-sygnatariuszy Konwencji. Orzecznictwo Trybunału wskazuje także na kierunki ochrony praw osób pozbawionych wolności. Przykładowo, orzecznictwo strasburskie tortury utożsamiało z nieludzkim postępowaniem skutkującym zasadniczymi, okrutnymi dolegliwościami ${ }^{36}$. Zgodnie z linią Europejskiego Trybunału Praw Człowieka, w sytuacji, gdy u osoby pozbawionej wolności doszło do obrażeń ciała, kiedy pozostawała pod kontrolą funkcjonariuszy, to na władzach państwowych spoczywa ciężar wykazania, że obrażenia spowodowane są innymi czynnikami niż złe traktowanie ${ }^{37}$.

\section{Europejska Konwencja o zapobieganiu torturom oraz nieludzkiemu lub poniżające- mu traktowaniu}

Postulując humanitarne wykonywanie kar, nie sposób pominąć Europejskiej Konwencji o zapobieganiu torturom oraz nieludzkiemu lub poniżającemu traktowaniu, podpisanej

35 J. Migdał, T. Szymanowski, op. cit., s. 53.

36 K. Postulski, Kodeks karny wykonawczy. Komentarz, Warszawa 2014, s. 81.

37 Ibidem. 
26 listopada 1987 roku (Dz. U. z 1995 r. Nr 46, poz. 238 z późn. zm.) ${ }^{38}$. Na mocy art. 1 powołano Europejski Komitet ds. Zapobiegania Torturom oraz Nieludzkiemu lub Poniżającemu Traktowaniu albo Karaniu, który przeprowadza wizytacje celem wzmocnienia tej ochrony. Przedstawiciele Komitetu mają swobodę poruszania się po terytorium państwa-strony, dostępu do informacji o miejscach przebywania osób pozbawionych wolności oraz w związku z tym prawo przeprowadzania wywiadu z tymi osobami. Wizytacje kończą się sprawozdaniem i ewentualnymi zaleceniami w celu lepszej ochrony pozbawionych wolności.

\section{Europejskie Reguły Więzienne}

Z kolei miękkim prawem będącym odpowiednikiem „Reguł minimalnych ONZ” są dla Państw Rady Europy Europejskie Reguły Więzienne (dalej: ERW), przyjęte przez Komitet Ministrów Rady Europy w dniu 11 stycznia 2006 roku. Wyrosły one ze wspólnego przekonania państw Rady Europy, że charakter norm Reguł Minimalnych ONZ jest zbyt ogólny ${ }^{39}$. Oczywiście część Reguł ma również charakter programowy. Zgodnie z pierwszą regułą wszystkie osoby pozbawione wolności są traktowane z poszanowaniem praw człowieka. Reguła 3 stanowi natomiast, że restrykcje nałożone na osoby pozbawione wolności powinny być ograniczone do koniecznego minimum i proporcjonalne do uzasadnionego celu. Podkreślają w sposób szczególny (reguła 102.2), że więzienie to kara sama w sobie i z tego powodu rygor wykonywania nie może przyczyniać się do pogorszenia cierpień związanych z osadzeniem. Reguły od 56.1 do 62 zawierają postanowienia normujące elementy związane $z$ karaniem dyscyplinarnym. Zgodnie z przepisami ERW pociągnięcie do odpowiedzialności dyscyplinarnej powinno mieć charakter rozwiązania ostatecznego. Europejskie Reguły Więzienne przyznają pierwszeństwo mechanizmom mediacyjnym i restytucyjnym w rozwiązywaniu sporów z więźniami. W odróżnieniu od Reguł Minimalnych ONZ, przepisy ERW konkretyzują, jakie przesłanki powinny zostać spełnione, aby zakwalifikować określone działanie jako przekroczenie. Zgodnie z regułą 57.1 za przekroczenie może zostać uznane działanie, które zagraża porządkowi, bezpieczeństwu instytucjonalnemu lub bezpieczeństwu osobistemu. Europejskie Reguły Więzienne postulują całkowity zakaz stosowania pewnych rodzajów kar dyscyplinarnych. Zabroniono stosowania kar: zbiorowych, cielesnych, umieszczania w ciemnej celi, całkowitego zakazu kontaktów z rodziną. Niedozwolone jest także stosowanie sprzętu do krępowania swobody ruchu jako formy karania dyscyplinarnego. W ERW postuluje się stosowanie kary izolacji w wyjątkowych okolicznościach oraz na czas możliwie najkrótszy.

38 J. Migdał, T. Szymanowski, op. cit., s. 56.

39 M. Płatek, Zadania polskiej polityki penitencjarnej w świetle Europejskich Regut Więziennych, [w:] „Czasopismo Prawa Karnego i Nauk Penalnych” 2007 z. 1, s. 262. 


\section{Problemy polskiego więziennictwa i ich wpływ na respektowanie zasady humanitaryzmu}

Respektowanie zasady humanitaryzmu wykonywania kary pozbawienia wolności jest także zdeterminowane przez faktyczne warunki, w jakich skazani odbywają karę. $Z$ tak ogólnym pojęciem wiążą się chociażby takie zagadnienia jak: stan infrastruktury sanitarnej, wentylacja cel, jakość opieki zdrowotnej w zakładach karnych oraz zapewnienie, aby powierzchnia celi, która przypada na jednego więźnia odpowiadała ustalonym standardom. Jednym ze strukturalnych problemów polskiego systemu więziennego jest zjawisko przeludnienia instytucji izolacyjnych. Zgodnie z obowiązującym prawem, stan przeludnienia występuje wtedy, gdy liczba osadzonych w zakładach karnych lub aresztach śledczych przekroczy w skali kraju ogólną pojemność tych zakładów ${ }^{40}$. W komunikacie Centralnego Zarządu Służby Więziennej z dnia 6 kwietnia 2012 roku poinformowano, że zaludnienie zakładów karnych i aresztów śledczych wynosi 100,3\% w skali kraju.

W doktrynie podkreśla się, że przeludnienie jednostek penitencjarnych może skutkować uniemożliwieniem osiągnięcia celów resocjalizacyjnych i wychowawczych kary pozbawienia wolności ${ }^{41}$. Trybunał Konstytucyjny zaznaczył, że nadmierne zaludnienie zakładów karnych może zostać uznane za traktowanie niehumanitarne, a w przypadku kumulacji innych niedogodności, również za torturę ${ }^{42}$.

Inną dziedziną, która powinna być przykładem realizacji zasady humanitaryzmu jest opieka zdrowotna w instytucjach izolacyjnych. Szczególna sytuacja, w jakiej znajdują się osoby pozbawione wolności, nakłada na administrację więzienną odpowiedzialność za stan zdrowia więźniów ${ }^{43}$.

W wyroku z dnia 28 lutego 2007 roku Sąd Najwyższy podkreślił, że w przypadku umieszczenia skazanego w przeludnionej celi bez dostępu do oddzielonej od reszty pomieszczenia toalety oraz węzła sanitarnego:

nie można uznać za uzasadniony i normalny element kary pozbawienia wolności, co wynika także z art. 110 § 2 k. k. w., w którym ustawodawca, dostosowując przepisy dotyczące wykonania kary pozbawienia wolności do norm prawa europejskiego, zawarł wymogi dotyczące warunków bytowych w celach mieszkalnych. ${ }^{44}$

40 Standardy Europejskiego Komitetu Zapobiegania Torturom. „, Merytoryczne” fragmenty sprawozdan ogólnych Europejskiego Komitetu Zapobiegania Torturom, Strasburg 2003.

41 G. Szczygieł, Zasada poszanowania godności skazanego a przeludnienie zaktadów karnych [w:] X lat obowiqzy wania Kodeksu karnego wykonawczego, Białystok 2009, s. 145.

42 Wyrok TK z dnia 26 maja 2008r., sygn. Sk 25/07.

43 Konwencja o Ochronie Praw Cztowieka i Podstawowych Wolności. Komentarz do artykutów 1-18. Tom I., red. Leszek Garlicki, Warszawa 2010, s. 126.

44 Wyrok SN z dnia 28 lutego 2007 r., sygn. V CSK 431/06. 
W kontekście standardów taktowania więźniów w Polsce, istotny jest problem nadmiernego stosowania środków ograniczających wobec więźniów niebezpiecznych ${ }^{45}$. Powstaje pytanie, czy nie godzą w jego godność i czy zastosowanie zbyt rygorystycznych środków może być uznane za humanitarne.

W ważnym dla respektowania zasady humanitaryzmu wyroku Trybunału Konstytucyjnego z 26 maja 2008 roku $^{46}$ został przytoczony raport Helsińskiej Fundacji Praw Człowieka, w którym wskazywała ona, że w Europejskim Trybunale Praw Człowieka znajduje się znaczna liczba skarg obywateli polskich, które dotyczą nieludzkich i poniżających warunków odbywania kary pozbawienia wolności związanych przede wszystkim z przeludnieniem jednostek penitencjarnych. Istnieje więc prawdopodobieństwo, że pociągnie to za sobą konsekwencje finansowe dla Polski ze względu na konieczność wypłaty wysokich odszkodowań przyznanych skarżącym przez ETPC.

Należy zaznaczyć, że problem humanitarnego traktowania osób odbywających karę pozbawienia wolności jest otwarty, zaś słowo „humanitarny” jest pojmowanie niejednolicie. Trafne i aktualne są słowa konstytucjonalisty, że „realizacja zasady humanitaryzmu powinna być zapewniona nie tylko poprzez właściwe regulacje prawne, lecz również przez odpowiednie traktowanie osadzonych przez personel zaangażowany w proces wykonywania kary pozbawienia wolności”47.

\section{SUMMARY}

\section{The principle of humanity in international and national standards of penitentiary law}

This paper points out the most important international and internal acts which refer to prisoners' rights in the context of the principle of humanity. The first part describes the Polish situation with regards to constitutional principles of human dignity and freedom from unfair treatment. The second part focuses on international standards, and is divided into two groups: UN standards and European standards. This leads to the conclusions contained in the third section about respecting these articles in contemporary Polish penitentiary law and prisons.

Keywords: humanity, European Court of Human Rights, European Convention on Human Rights, prisoners' rights, dignity, Polish Constitution, Polish criminal code, penitentiary law

45 E. Dawidziuk, Prawa tzw. osadzonych niebezpiecznych na tle wyroków ETPC w sprawach przeciwko Polsce, [w:] Prawa cztowieka a polski system penitencjarny. Edukacja.Resocjalizacja.Humanitaryzm, red. Dorota Rondalska, Poznań-Kule 2012, s. 36 i n.

46 Wyrok TK z dnia 26 maja 2008 r., sygn. Sk 25/07.

47 P. Winczorek, Komentarz do Konstytucji Rzeczypospolitej Polskiej z dnia 2 kwietnia 1997 roku, Warszawa 2008, s. 104. 